\title{
ARTHRITIS ASSOCIATED WITH VENEREAL DISEASE* \\ A COMPARATIVE STUDY OF GONOCOCCAL ARTHRITIS AND REITER'S SYNDROME
}

\author{
BY \\ V. WRIGHT $\dagger$ \\ From the Department of Medicine, Johns Hopkins University School of Medicine, Baltimore, Maryland
}

\begin{abstract}
Although the existence of gonococcal arthritis has been recognized for many years, the clearer delineation of Reiter's syndrome has cast doubt upon the value of many former descriptions of the disease. It is evident that cases of Reiter's syndrome, sometimes with co-existing gonococcal urethritis, have been included in series from which deductions concerning the clinical picture of gonococcal arthritis have been drawn.

An analysis has, therefore, been made of 214 cases of arthritis thought to be associated with venereal disease, seen at the Johns Hopkins Hospital, to provide a comparative description of gonococcal arthritis (gc. arthritis) and Reiter's syndrome in the same hospital population. Another aim of the study has been to determine the similarities between cases of proven gc. arthritis and those in which the diagnosis was considered likely, although no organism was grown from the joint, and thus to test the probability of such a diagnosis being correct. The differences between definite gc. arthritis and other pyogenic arthritides have been shown and their significance assessed. This study is of necessity retrospective, with the usual attendant limitations, but this method of approach seemed to be the best in view of the changing pattern of venereal disease.
\end{abstract}

\section{Material and Methods}

The case notes of 214 patients classified as cases of gc. arthritis were arranged in three categories:

(1) Definite Gc. Arthritis.-In these cases gonococci were recovered from a joint or tendon sheath effusion by smear or culture.

(2) Probable Gc. Arthritis.-In these cases no gonococci were recovered from a joint, but gonococcal

* This paper was presented in part before The Medical Society for the Study of Venereal Diseases on January 26, 1962.

$\dagger$ Present address: Rheumatism Research Unit, University Department of Clinical Medicine, Leeds. urethritis or cervicitis was proven on smear or culture, the arthritis occurred within 3 weeks of a gonococcal infection, and the urogenital and articular manifestations responded to anti-gonococcal therapy.

(3) Reiter's Syndrome.-In these cases inflammatory arthritis followed an abacterial urethritis. Gonococcal urethritis was also present in some, but with specific therapy the gonococci disappeared without influencing the arthritis and leaving a persistent abacterial urethritis. Conjunctivitis was not considered to be essential for the diagnosis of Reiters' syndrome, since it may appear much later in the course of the disease, or may be so mild that it is missed.

Exclusions. -62 of the 214 patients were excluded from the final analysis.

In nineteen of these, further investigation and follow up revealed other diagnoses: eight had rheumatoid arthritis, three had rheumatic fever, three had arthritis associated with drug sensitivity reaction, two had colitic arthritis (Wright and Watkinson, 1960), and there were single cases of tuberculosis, the shoulder-hand syndrome, and sickle-cell anaemia.

Eleven patients had fibrous ankylosis of a joint seen at a late stage and attributed to gonorrhoea without any present evidence.

In eight patients no record of a search for gonococci was found, or the investigation was done after the institution of treatment.

In ten patients a purulent urethral or vaginal discharge and an inflammatory arthritis were present, and both cleared rapidly and completely on anti-gonococcal treatment, with no residual chronic mucoid discharge. Clinically, therefore, the diagnosis of gonococcal arthritis seemed possible, but no organism was isolated.

Fourteen patients had no evidence of gonorrhoea and none of pelvic inflammatory disease, the diagnosis having apparently been made from the character of the patient, rather than the character of the disease.

Thirteen of these excluded patients were seen before the advent of sulphonamides, 22 were treated with sulphonamides, 23 with penicillin, and for four there was no record of treatment. 


\section{Composition of Series Studied}

Sex and Ethnic Group.-Of the 152 patients included in the final analysis, 29 had definite gonococcal arthritis, 72 probable gonococcal arthritis, and 51 Reiter's syndrome. Their distribution in relation to sex, ethnic group, and diagnosis is shown in Table I. More coloured patients than white had gc. arthritis, but the reverse was true, though not so markedly, with Reiter's syndrome. There was a preponderance of women with gc. arthritis which was very striking where the diagnosis was definite (approximately 6 women to 1 man), and very few women had Reiter's syndrome.

In the following analysis figures for each sex have only been given separately where they showed differences or points of particular interest.

Age at Examination.-At the time of examination the majority of patients were aged from 16 to 35 years, only seventeen being less than 16 years old and only 21 more than 35 years old (Table II). The age distribution in the three categories was similar, except that there were relatively more with probable gc. arthritis under 15 years and more with Reiter's syndrome in the decade 26-35 years. The percentage distribution is also shown in Table II.
Era of Treatment.-Three eras of treatment may be distinguished: pre-sulphonamide, sulphonamide, and penicillin. 42 patients were treated before sulphonamides were available, 84 with sulphonamides, and 26 with penicillin.

There was little change in the relative frequency of Reiter's syndrome in each era, but there was a fall of the incidence of definite gc. arthritis, which was diagnosed less than half as frequently in the third period when penicillin was used than in the first period before sulphonamides were available (Table III, opposite). There was a corresponding increase in the last period of the incidence of those with probable gc. arthritis.

\section{Onset of Arthritis}

Age at Onset.-The age at onset was close to the age at examination (as shown in Table II) in the patients with definite and probable gc. arthritis, but in a good many of those with Reiter's syndrome the onset preceded the time of examination by some years.

The greatest number of patients in each category began to experience joint symptoms between 16 and 25 years of age. The percentage distribution in definite and probable gc. arthritis was similar,

TABLE I

ETHNIC GROUPS OF PATIENTS WITH ARTHRITIS ASSOCIATED WITH VENEREAL DISEASE, BY SEX AND DIAGNOSIS

\begin{tabular}{|c|c|c|c|c|c|c|c|c|c|c|c|c|}
\hline & & & \multicolumn{6}{|c|}{ Gonococcal Arthritis } & \multirow{2}{*}{\multicolumn{3}{|c|}{ Reiter's Syndrome }} & \multirow{3}{*}{$\begin{array}{c}\text { Total } \\
\text { Patients }\end{array}$} \\
\hline \multirow{2}{*}{\multicolumn{3}{|c|}{ Race }} & \multicolumn{3}{|c|}{ Definite } & \multicolumn{3}{|c|}{ Probable } & & & & \\
\hline & & & \multirow{2}{*}{$\begin{array}{c}\text { Male } \\
3 \\
1\end{array}$} & \multirow{2}{*}{$\begin{array}{c}\text { Female } \\
\begin{array}{c}18 \\
7\end{array}\end{array}$} & \multirow{2}{*}{$\begin{array}{c}\text { Total } \\
21 \\
8 \\
\end{array}$} & \multirow{2}{*}{$\begin{array}{c}\text { Male } \\
13 \\
12\end{array}$} & \multirow{2}{*}{$\begin{array}{c}\text { Female } \\
38 \\
9\end{array}$} & \multirow{2}{*}{$\begin{array}{c}\text { Total } \\
51 \\
21 \\
\end{array}$} & \multirow{2}{*}{$\begin{array}{c}\text { Male } \\
19 \\
28 \\
\end{array}$} & \multirow{2}{*}{$\begin{array}{c}\text { Female } \\
3 \\
1 \\
\end{array}$} & \multirow{2}{*}{$\begin{array}{c}\text { Total } \\
22 \\
29\end{array}$} & \\
\hline $\begin{array}{l}\text { Coloured } \\
\text { White }\end{array}$ & $\begin{array}{l}\cdots \\
\cdots\end{array}$ & $\begin{array}{l}\cdots \\
\cdots\end{array}$ & & & & & & & & & & $\begin{array}{l}94 \\
58\end{array}$ \\
\hline Tot & . & .. & 4 & 25 & 29 & 25 & 47 & 72 & 47 & 4 & 51 & 152 \\
\hline
\end{tabular}

TABLE II

AGE AT EXAMINATION, BY DIAGNOSIS

\begin{tabular}{|c|c|c|c|c|c|c|c|c|c|c|c|c|c|}
\hline & & & \multicolumn{10}{|c|}{ Age Group (yrs) } & \multirow{3}{*}{$\begin{array}{c}\text { Total } \\
\text { Patients }\end{array}$} \\
\hline \multirow{2}{*}{\multicolumn{3}{|c|}{ Diagnosis }} & \multicolumn{2}{|r|}{$0-15$} & \multicolumn{2}{|c|}{$16-25$} & \multicolumn{2}{|c|}{$26-35$} & \multicolumn{2}{|c|}{$36-45$} & \multicolumn{2}{|c|}{$46+$} & \\
\hline & & & No. & Per cent. & No. & Per cent. & No. & Per cent. & No. & Per cent. & No. & Per cent. & \\
\hline \multirow{2}{*}{$\begin{array}{l}\text { Gonococcal } \\
\text { Arthritis }\end{array}$} & Definite & .. & 2 & 7 & 19 & 70 & 3 & 9 & 1 & 4 & 4 & 10 & 29 \\
\hline & Probable & 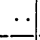 & 14 & 20 & 42 & 60 & 9 & 10 & 6 & 8 & 1 & 2 & 72 \\
\hline \multicolumn{2}{|c|}{ Reiter's Syndrome } & $\cdots$ & 1 & 2 & 21 & 41 & 20 & 39 & 7 & 14 & 2 & 4 & 51 \\
\hline Total & $\ldots$ & . & 17 & & 82 & & 32 & & 14 & & 7 & & 152 \\
\hline
\end{tabular}


TABLE III

INCIDENCE OF ARTHRITIS IN DIFFERENT ERAS OF TREATMENT, BY SEX AND DIAGNOSIS

There are fewer patients with definite gonococcal arthritis in each succeeding era

\begin{tabular}{|c|c|c|c|c|c|c|c|c|c|c|c|c|c|c|c|}
\hline \multirow{4}{*}{ Dia } & & & \multicolumn{12}{|c|}{ Treatment Era } & \multirow{4}{*}{$\begin{array}{c}\text { Total } \\
\text { Patients }\end{array}$} \\
\hline & is & & \multirow{3}{*}{ Male } & \multicolumn{3}{|c|}{ Pre-sulphonamide } & \multicolumn{4}{|c|}{ Sulphonamide } & \multicolumn{4}{|c|}{ Penicillin } & \\
\hline & iosis & & & \multirow{2}{*}{ Female } & \multicolumn{2}{|c|}{ Total } & \multirow{2}{*}{ Male } & \multirow{2}{*}{ Female } & \multicolumn{2}{|c|}{ Total } & \multirow{2}{*}{ Male } & \multirow{2}{*}{ Female } & \multicolumn{2}{|c|}{ Total } & \\
\hline & & i & & & No. & $\%$ & & & No. & $\%$ & & & No. & $\%$ & \\
\hline \multirow{2}{*}{$\begin{array}{c}\text { Gonococcal } \\
\text { Arthritis }\end{array}$} & Definite & $\ldots$ & 2 & 9 & 11 & 26 & 2 & 13 & 15 & 18 & - & 3 & 3 & 11 & 29 \\
\hline & Probable & $\cdots$ & 9 & 10 & 19 & 45 & 12 & 25 & 37 & 44 & 4 & 12 & 16 & 61 & 72 \\
\hline \multicolumn{2}{|c|}{ Reiter's Syndrome . . } & $\cdots$ & 10 & 2 & 12 & 29 & 31 & 1 & 32 & 38 & 6 & 1 & 7 & 27 & 51 \\
\hline \multicolumn{2}{|c|}{ Total } & $\ldots$ & 21 & 21 & 42 & 100 & 45 & 39 & 84 & 100 & 10 & 16 & 26 & 99 & 152 \\
\hline
\end{tabular}

except that the arthritis began before age 16 in 20 per cent. of the probable cases and in only 7 per cent. of the definite cases.

In Reiter's syndrome the arthritis began after age 25 in 23 of the 51 patients (45 per cent.) compared with 23 per cent. of those with definite and 20 per cent. of those with probable gc. arthritis.

The percentage distribution of the age at onset is shown for each category in Fig. 1.

Joints Involved.-The onset was polyarticular in just over half the patients with Reiter's syndrome (26 of 51 patients), whereas it was monarticular in the majority of other patients (17 of 29 definite, and 57 of 72 probable). The arthritis began acutely in the majority of patients (93 per cent. of those with definite and probable gc. arthritis), although it was more often insidious in those with Reiter's syndrome (26 per cent. acute onset). It was commonly accompanied by constitutional disturbances, and pyrexia was usually present at the time of admission to hospital (88 per cent. definite, 90 per cent. probable). In Reiter's syndrome, although frequent, pyrexia was less common (62 per cent.). In more than half the patients in all three groups the temperature rose to over $101^{\circ} \mathrm{F}$.

The joints involved initially are shown in Fig. 2 (overleaf). The frequency is similar for most joints, but the shoulder, which was often involved in definite ( 24 per cent.) and probable (18 per cent.) gc. arthritis, was less frequently affected in Reiter's syndrome ( 8 per cent.). Furthermore, the elbow was never involved initially in Reiter's syndrome, and it was only in this disease that the heel produced symptoms at onset (both these differences are significant: $P<0.01$ ).

In all three groups the central joints were commonly affected at the onset and in 80 per cent. or more the arthritis was asymmetrical initially
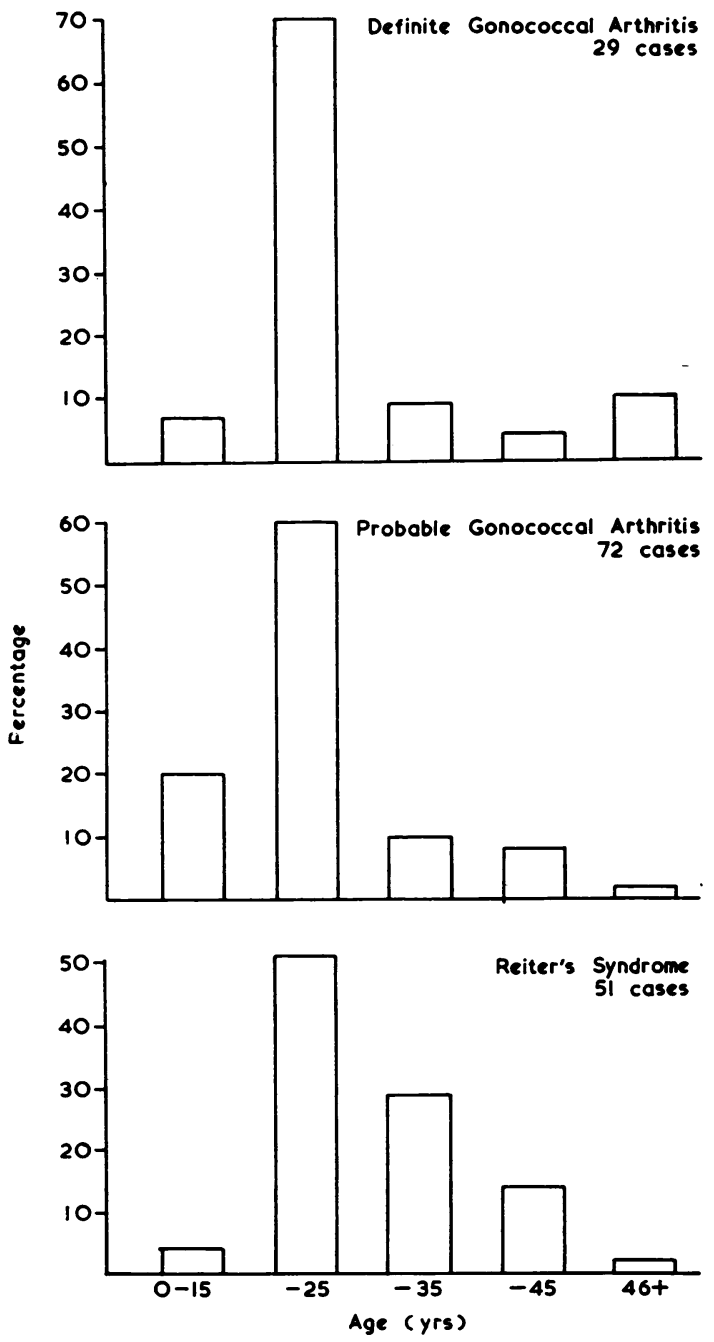

Fig. 1.-Age at time of onset of arthritis. 

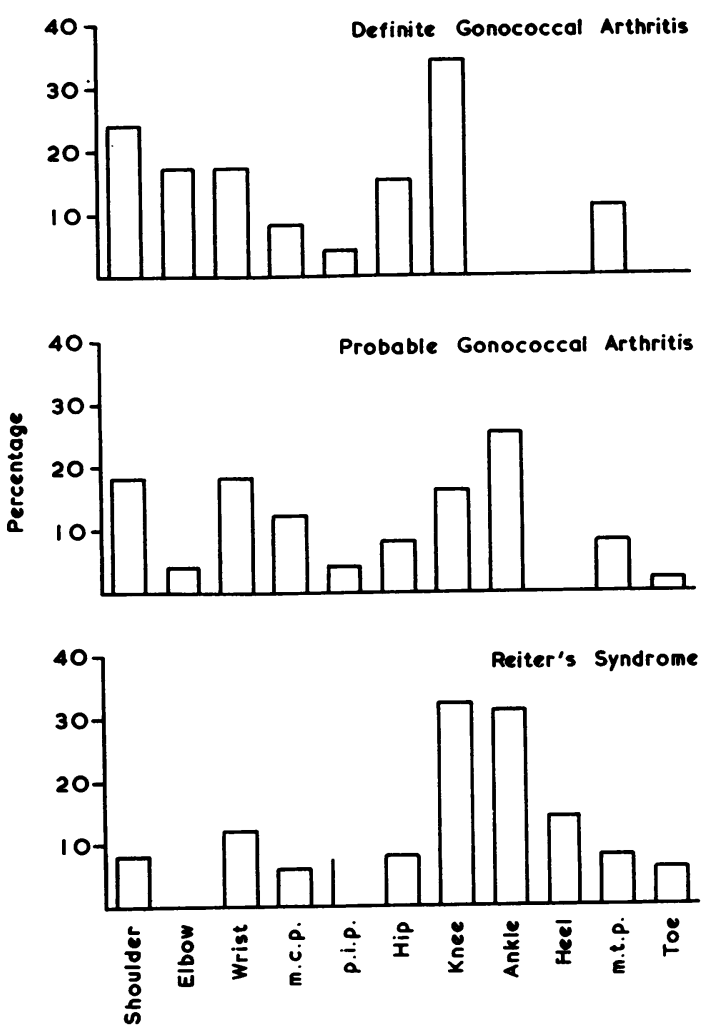

Fig. 2.-Frequency of joints involved initially in arthritis associated with venereal disease.
(Table IV). The upper limbs, in which arthritis began in over half the patients with definite or probable gc. arthritis, were involved in only 14 per cent. of those with Reiter's syndrome (a significant difference: $P<0.01)$.

\section{Course of Arthritis}

Joints Involved.-The frequency of joints involved during the course of arthritis is shown in Table V. There was little difference between the three categories. It was of interest that the temporomandibular joint was involved in only 14 per cent. of patients with definite gc. arthritis. The lumbar spine was more frequently involved in Reiter's syndrome, as was the heel. In three patients with definite and in fifteen with probable gc. arthritis a tenosynovitis was observed, but this was not seen in Reiter's syndrome.

With few exceptions the central joints and those of the lower limbs were involved in all patients (Table VI, opposite). Peripheral joints were more often involved in Reiter's syndrome and in 24 per cent. the arthritis was symmetrical, compared with only five in the other groups. A migratory polyarthritis was a relatively rare component of the clinical picture in Reiter's syndrome.

\section{Duration and Recurrences}

The mean period of follow up was, definite gc. arthritis 4.5 years, probable gc. arthritis 6.5 years, and Reiter's syndrome 6.4 years. The distribution of patients in relation to the follow up was similar.

TABLE IV

PERCENTAGE DISTRIBUTION OF JOINTS INVOLVED AT ONSET, BY DIAGNOSIS All three groups are similar except that the upper limb joints were least often affected in Reiter's syndrome

\begin{tabular}{|c|c|c|c|c|c|c|}
\hline \multirow{2}{*}{\multicolumn{3}{|c|}{ Diagnosis }} & \multicolumn{3}{|c|}{ Joint Involvement (per cent.) } & \multirow{3}{*}{$\begin{array}{c}\text { Total Patients } \\
29\end{array}$} \\
\hline & & & \multirow{2}{*}{$\frac{\text { Central }}{76}$} & \multirow{2}{*}{$\frac{\text { Asymmetrical }}{83}$} & \multirow{2}{*}{$\frac{\text { Upper Limbs }}{55}$} & \\
\hline \multirow{2}{*}{ Gc. Arthritis } & Definite .. & . & & & & \\
\hline & Probable & $\cdots$ & 72 & 100 & 56 & 72 \\
\hline \multicolumn{2}{|c|}{ Reiter's Syndrome } & . & 65 & 80 & 14 & 51 \\
\hline
\end{tabular}

TABLE V

PERCENTAGE FREQUENCY OF JOINTS INVOLVED, BY DIAGNOSIS

\begin{tabular}{|c|c|c|c|c|c|c|c|c|c|c|c|c|c|c|c|c|}
\hline \multirow{2}{*}{\multicolumn{2}{|c|}{ Diagnosis }} & \multirow{3}{*}{$\frac{\begin{array}{c}\text { Temporo- } \\
\text { man- } \\
\text { dibular }\end{array}}{14}$} & \multirow{3}{*}{$\begin{array}{c}\begin{array}{c}\text { Sterno- } \\
\text { clavic- } \\
\text { ular }\end{array} \\
17\end{array}$} & \multirow{3}{*}{\begin{tabular}{|c}
$\begin{array}{c}\text { Shoul- } \\
\text { der }\end{array}$ \\
45
\end{tabular}} & \multirow{3}{*}{$\frac{\text { Elbow }}{38}$} & \multirow{3}{*}{ Wrist } & \multicolumn{4}{|c|}{ Joints Involved (per cent.) } & \multirow{3}{*}{$\begin{array}{c}\text { Hip } \\
24\end{array}$} & \multirow{3}{*}{$\frac{\text { Knee }}{86}$} & \multirow{3}{*}{ Ankle } & \multirow{3}{*}{$\begin{array}{r}\text { Heel } \\
7\end{array}$} & \multirow{3}{*}{$\frac{\text { Mtp }}{21}$} & \multirow{3}{*}{$\begin{array}{r}\text { Toe } \\
3\end{array}$} \\
\hline & & & & & & & Mcp & Pip & $\begin{array}{l}\text { Cer- } \\
\text { vical }\end{array}$ & Lum- & & & & & & \\
\hline \multirow{2}{*}{$\begin{array}{c}\text { Gc. } \\
\text { Arthritis }\end{array}$} & Definite. . & & & & & & 17 & 17 & 17 & 7 & & & & & & \\
\hline & Probable & 3 & 4 & 47 & 24 & 47 & 24 & 14 & 11 & 4 & 15 & 45 & 49 & 4 & 14 & 3 \\
\hline \multicolumn{2}{|c|}{ Reiter's Syndrome } & 10 & 14 & 47 & 30 & 39 & 16 & 18 & 20 & 31 & 27 & 90 & 73 & 35 & 31 & 20 \\
\hline
\end{tabular}


TABLE VI

PERCENTAGE DISTRIBUTION OF JOINTS AFFECTED, BY DIAGNOSIS

In Reiter's syndrome the peripheral joints are more frequently involved, and the arthritis is more often symmetrical, but less of ten migratory

\begin{tabular}{|c|c|c|c|c|c|c|c|c|c|c|}
\hline \multirow{2}{*}{\multicolumn{4}{|c|}{ Diagnosis }} & \multicolumn{6}{|c|}{ Joints Affected (per cent.) } & \multirow[b]{2}{*}{$\begin{array}{c}\text { Total } \\
\text { Patients }\end{array}$} \\
\hline & & & & Central & Peripheral & $\begin{array}{l}\text { Upper } \\
\text { Limbs }\end{array}$ & $\begin{array}{l}\text { Lower } \\
\text { Limbs }\end{array}$ & $\begin{array}{c}\text { Sym- } \\
\text { metrical }\end{array}$ & Migratory & \\
\hline \multirow{2}{*}{ Gc. Arthritis } & Definite & $\cdots$ & $\cdots$ & 97 & 52 & 83 & 93 & 10 & 38 & 29 \\
\hline & Probable & $\cdots$ & $\cdots$ & 92 & 37 & 78 & 97 & 3 & 25 & 72 \\
\hline \multicolumn{2}{|c|}{ Reiter's Syndrome } & $\cdots$ & $\cdots$ & 100 & 69 & 73 & 98 & 24 & 8 & 51 \\
\hline
\end{tabular}

Acute attacks of definite and probable gc. arthritis subsided within 4 weeks in the majority of patients (Fig. 3), only six definite and seven probable
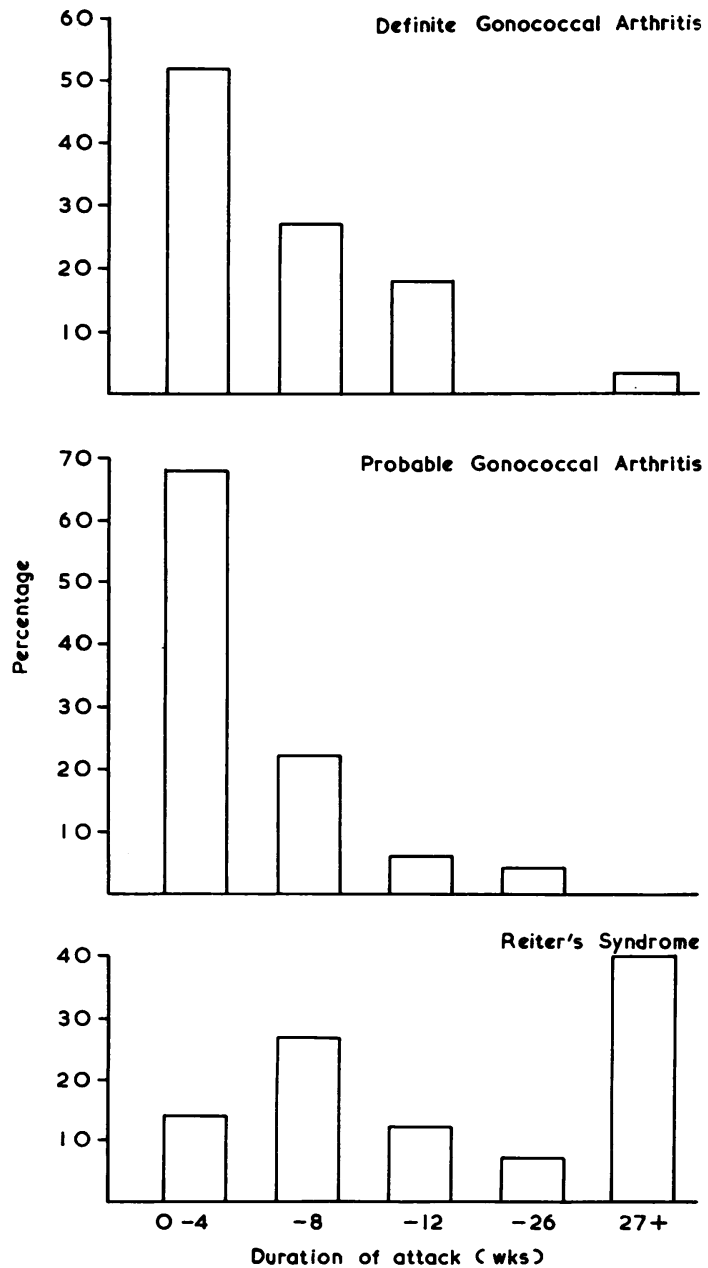

Fig. 3.-Duration of acute attack in arthritis associated with venereal disease. cases having an attack lasting more than 8 weeks. By contrast, the arthritis in 59 per cent. of patients with Reiter's syndrome lasted more than 8 weeks, and in only 14 per cent. did it subside within 4 weeks. The shorter duration in cases of gc. arthritis was due in part to the advent of more effective treatment. All the six patients in whom definite gc. arthritis lasted longer than 8 weeks presented before sulphonamides were available, as did five of those with probable gc. arthritis. The patients with arthritis of over 8 weeks' duration having Reiter's syndrome were scattered throughout the three treatment eras, seven before sulphonamides, eighteen treated with sulphonamides and five treated with penicillin, the incidence in each era being 58 per cent., 56 per cent., and 71 per cent. respectively.

Recurrences were uncommon in patients with gc. arthritis (definite 7 per cent.; probable 8 per cent.), but frequent in those with Reiter's syndrome (63 per cent.). Six patients with probable gc. arthritis had two attacks, one with definite gc. arthritis had three and the other more than five attacks. Of the patients with Reiter's syndrome, thirteen had two attacks, eight had three attacks, four had five attacks, and seven had numerous recurrences on more than five occasions.

Residual Disability (Table VII, overleaf).-In all categories limitation of knee, hip, and wrist movement were important sequelae. Limitation of ankle movement, although seen in all categories, was more common in cases of Reiter's syndrome. More of the latter had residual joint damage, and only in them was there limitation of movement of the shoulders and spine. The spinal stiffness was clinically like that seen in ankylosing spondylitis, with flattening of the lumbar segment and restriction of back movement in all directions. Painful heels and painful metatarsophalangeal joints were other features of a chronic nature confined to cases of Reiter's syndrome. Of the 25 patients with joint 
TABLE VII

JOINTS SHOWING RESIDUAL DISABILITY FOLLOWING ACTIVE PHASE OF ARTHRITIS, BY DIAGNOSIS

\begin{tabular}{|c|c|c|c|c|c|c|c|c|c|c|c|c|}
\hline \multirow{2}{*}{\multicolumn{3}{|c|}{ Diagnosis }} & \multicolumn{9}{|c|}{ Joints showing Residual Disabilitv } & \multirow{2}{*}{$\begin{array}{c}\text { Total } \\
\text { Patients }\end{array}$} \\
\hline & & & Hip & Knee & Ankle & Spine & Shoulder & Wrist & Finger & Heel & Mtp & \\
\hline \multirow{2}{*}{ Gc. Arthritis } & Definite & $\cdots$ & 1 & 6 & 1 & - & - & 2 & - & - & - & 9 \\
\hline & Probable & $\cdots$ & 2 & 2 & 1 & - & - & - & 一 & - & - & 5 \\
\hline \multicolumn{2}{|c|}{ Reiter's Syndrome } & $\cdots$ & 1 & 5 & 6 & 7 & 2 & 3 & 1 & 8 & 8 & 23 \\
\hline
\end{tabular}

sequelae after the acute phase of Reiter's syndrome, twelve had disability in more than one joint, whereas only one other patient (a case of definite gc. arthritis) had more than one joint permanently damaged.

More patients with gc. arthritis developed residual disability before sulphonamides were available than after, but in all treatment eras the majority showed no clinical signs of permanent joint damage (Table VIII).

The advent of new drugs made no difference to the incidence of joint damage in cases of Reiter's syndrome; indeed, relatively more had residual disability when sulphonamides and penicillin were used (49 per cent.) than before these drugs were available (33 per cent.).

\section{Non-articular Lesions}

Ocular--Conjunctivitis was observed in two patients with definite gc. arthritis (7 per cent.) and gonococci were grown from one of them. Three patients with probable gc. arthritis (4 per cent.) developed conjunctivitis. Ocular lesions were observed in 22 patients with Reiter's syndrome (44 per cent.), nineteen having conjunctivitis and seven uveitis.

Mucocutaneous.-Keratodermia blennorrhagica developed during the period of observation in three patients with Reiter's syndrome, but was not seen at all in the other cases.

One patient with probable gc. arthritis had erythema nodosum.
Circinate balanitis was seen only in seven patients with Reiter's syndrome.

Ulceration of the buccal mucous membrane during the period of active arthritis was recorded in four patients with Reiter's syndrome, one with definite gc. arthritis, and one with probable gc. arthritis.

\section{Laboratory Investigations}

Bacteriology.-The diagnosis of definite gc. arthritis required the isolation of gonococci from joint fluid or tendon sheath effusion. In fourteen patients, Gramnegative intra-cellular diplococci were seen on smear, in 24 they were cultured, and in nine they were obtained by both smear and culture. Search for gonococci was made in joint aspirate from nineteen patients with probable gc. arthritis and 23 with Reiter's syndrome, without result.

The urogenital tract was investigated for gonococci in men by examination of the urethral discharge and sometimes of the secretion following prostatic massage. In women the vaginal discharge or cervical smear was examined. Twelve patients with definite gc. arthritis showed gonococci on smear, ten on culture, and five on both. In probable gc. arthritis, gonococci were seen in 51 patients on microscopic examination, in 41 on culture, and in twenty on both. Gonococci were less readily demonstrable in the urogenital tract of women than men; in those with definite gc. arthritis the organism was isolated from the urethral discharge of all the men, but of only 44 per cent. of the women. The presence of gonococci in the urogenital tract was a criterion of the diagnosis of probable gc. arthritis; the organism was demonstrated by smear and culture in 40 per cent. of the men, but in only 28 per cent. of the women.

TABLE VIII

PATIENTS WITH RESIDUAL DISABILITY, BY DIAGNOSIS AND TREATMENT ERA, EXPRESSED AS FRACTION OF THOSE TREATED

Joint damage resulted more frequently before specific drugs were available in cases of gc. arthritis, but their advent made no difference in cases of Reiter's syndrome

\begin{tabular}{|c|c|c|c|c|c|c|}
\hline \multirow{2}{*}{\multicolumn{4}{|c|}{ Diagnosis }} & \multicolumn{3}{|c|}{ Treatment Era } \\
\hline & & & & Pre-sulphonamide & Sulphonamide & Penicillin \\
\hline \multirow{2}{*}{ Gc. Arthritis } & Definite .. & .. & .. & $5 / 11$ & $3 / 15$ & $1 / 3$ \\
\hline & Probable & . & .. & $4 / 19$ & $1 / 37$ & $0 / 16$ \\
\hline \multicolumn{2}{|c|}{ Reiter's Syndrome } & . & .. & $4 / 12$ & $15 ! 32$ & $4 / 7$ \\
\hline
\end{tabular}


In Reiter's syndrome there was concomitant gonococcal infection in 23 patients (45 per cent.); the organism was demonstrated by smear in twenty, by culture in ten, and by both in seven.

Gonococcal Complement-Fixation Test (G.C.F.T.).This was not done routinely on all patients; of 38 with definite or probable gc. arthritis five (12 per cent.) gave negative results. Of 32 with Reiter's syndrome 27 (84 per cent.) gave a positive test, compared with 86 per cent. positive in definite and 90 per cent. in probable gc. arthritis.

Haemoglobin.-Mild anaemia was common, nine patients with definite and nine with probable gc. arthritis having haemoglobin levels below 70 per cent. (Table IX).

Erythrocyte Sedimentation Rate (E.S.R.).-Most patients in all groups had a rate above $20 \mathrm{~mm}$. in the first hour (Table IX), and some had values above $40 \mathrm{~mm}$., especially those with probable gc. arthritis.

White Blood Count.-A leucocytosis of more than 12,000 white blood cells per c.mm. was found more commonly in patients with definite and probable gc. arthritis than in those with Reiter's syndrome (Table IX). In only two of the last group did the count exceed 16,000 per c.mm., a significant difference $(P<0.05)$.

Serological Test for Syphilis.-In 11 to 17 per cent. of all groups the serological test for syphilis was positive: definite (3 of 26), probable (7 of 54), Reiter's syndrome (7 of 41).

Radiology.- $X$-ray examinations were carried out in 109 patients, and were classified as normal or abnormal on the following criteria: juxta-articular osteoporosis, narrowing of joint space, articular erosion, ankylosis. Of the patients $x$-rayed, more of those with Reiter's syndrome showed abnormalities than the rest (Table X), over half the films showing bone involvement.

Autopsy Findings.- Three patients died in hospital, all of whom presented before sulphonamides were available. The autopsy findings were as follows:

\section{Definite Gc. Arthritis}

Case 1, a 26-year-old coloured woman, who was 8 months pregnant, developed pain in the left shoulder, followed by polyarthritis, spreading to the left wrist and then the right shoulder, right wrist, ankles, and temporo-mandibular joints. Her husband had a chronic urethral discharge which had flared up a month preceding the patient's admission. At the time of admission her temperature was $100 \cdot 4^{\circ} \mathrm{F}$., and her pulse rate 140 per minute. She had a mild sore throat. Gonococci were seen in a smear of the vaginal discharge; 60 and 40 c.c. fluid were aspirated from the right knee on two occasions and gonococci were cultured each time. The haemoglobin level was 72 per cent. and a white cell count was 14,000 per c.mm. The serological test for syphilis was negative.

Salicylate therapy conferred no benefit. Her sore throat became worse, a yellow tough membrane developed, and the throat was red and oedematous. She developed dyspnoea and stridor, became comatose, and died 2 months after admission to hospital.

At autopsy an abscess containing gonococci was found to be present between the sixth and seventh cartilages at the margin of the sternum. This contained numerous leucocytes and mononuclear cells and was lined with granulation tissue. The left wrist contained a small amount of clear fluid. Just under the cartilage and at the margin of what should have been the marrow cavity, one or two groups of cells containing a few leucocytes were found among the laminae of bone.

TABLE IX

HAEMOGLOBIN LEVEL, ERYTHROCYTE SEDIMENTATION RATE, AND WHITE BLOOD COUNT IN CASES OF ARTHRITIS ASSOCIATED WITH VENEREAL DISEASE, BY DIAGNOSIS

\begin{tabular}{|c|c|c|c|c|c|c|c|c|c|c|c|c|c|c|c|c|}
\hline & \multirow{2}{*}{ Diagnosis } & & & & \multicolumn{3}{|c|}{$\begin{array}{c}\text { Haemoglobin } \\
\text { (per cent.) }\end{array}$} & \multicolumn{4}{|c|}{$\underset{(\mathrm{mm} .1 \mathrm{st} \mathrm{hr})}{\text { E.S.R. }}$} & \multicolumn{5}{|c|}{$\begin{array}{l}\text { White Blood Count } \\
\text { (thousands) }\end{array}$} \\
\hline & & & & & -70 & -85 & $86+$ & -20 & -40 & -60 & $61+$ & -8 & -12 & -16 & -20 & $20+$ \\
\hline \multirow{2}{*}{ Gc. Arthritis } & Definite & . & $\ldots$ & $\cdots$ & 9 & 9 & 11 & 1 & 8 & 1 & 3 & 3 & 12 & 8 & 4 & 2 \\
\hline & Probable & $\ldots$ & $\ldots$ & $\ldots$ & 9 & 22 & 37 & 5 & 9 & 32 & - & 10 & 29 & 20 & 10 & 2 \\
\hline \multicolumn{2}{|c|}{ Reitur's Syndrome .. } & . & . &. & - & 13 & 34 & 7 & 16 & 8 & 2 & 11 & 23 & 10 & 1 & 1 \\
\hline
\end{tabular}

TABLE X

PATIENTS WITH RADIOLOGICAL ABNORMALITIES, BY DIAGNOSIS

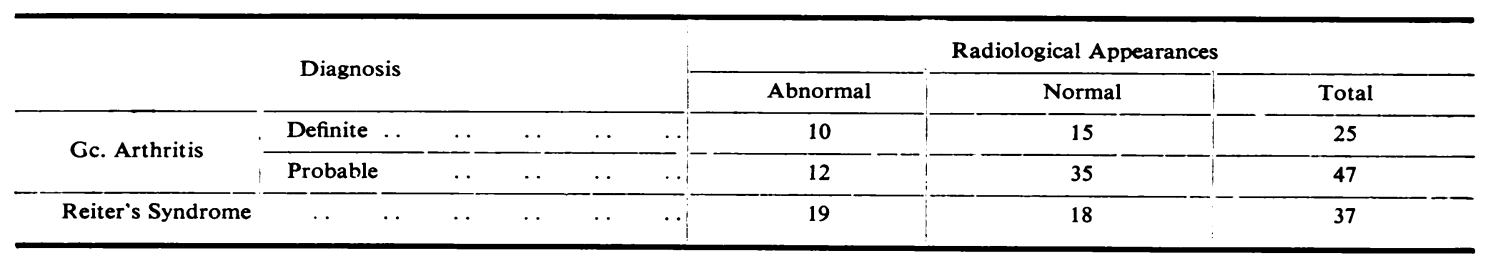


These stood out sharply in contrast to the marrow deeper in the shaft of the ulna, which was mostly fat. The left axillary nodes were swollen and oedematous. There was acute splenic swelling, punctate haemorrhages in the kidneys, haemorrhagic cystitis, thrombosis of the veins of the broad ligaments, old pleural adhesions, and diffuse bronchopneumonia affecting mainly the left lung.

\section{Probable Gc. Arthritis}

Case 2, a 22-year-old coloured woman, was said to have sprained the right ankle 2 weeks previously. She was desperately ill on admission. Her temperature was $103 \cdot 4^{\circ} \mathrm{F}$. and the left tarsus was exquisitely tender on the inner aspect, with a little swelling. She died 6 hours later. The white blood count was 35,000 per c.mm., the serological test for syphilis was positive, the urine contained 30-40 white cells per high-power field, and the gonococcal complement-fixation test was positive. At autopsy a chronic rheumatic endocarditis with aortic and mitral insufficiency was found. A gonococcal endocarditis of the aortic valve was present, there were gonococcal vegetations at the base of the tricuspid valve. A fibrino-purulent pericarditis was present, and the appearances of a gonococcal septicaemia with a septic choroiditis. No examination of the joint was permitted.

Case 3, a 20-year-old coloured woman with congenital syphilis, had had a white vaginal discharge for 2 months. Gonococci were seen on cervical smear. The left foot began to ache, and after 3 days became swollen, red, and extremely painful over the dorsal and lateral aspects. At this stage she was admitted to hospital and noted to have a temperature of $101 \cdot 2^{\circ} \mathrm{F}$. She was treated with hyperpyrexia in the Kettering hot box and died as a result. At autopsy, around the left ankle there was considerable oedema subcutaneously and in the connective tissue beneath the corium. The periarticular tissues showed oedema and infiltration, with many lymphocytes, plasma cells, and polymorphs. In the joint capsule there were small numbers of large mononuclear cells, a few red blood cells, and occasional polymorphs. The nearby lymph spaces were filled with coagulated protein and leucocytes. No organisms were demonstrated.

\section{Discussion}

Although arthritis has long been recognized as a complication of venereal disease, diagnosis has often been confused by a failure to distinguish between gonococcal arthritis (gc. arthritis) and the arthritis associated with abacterial ("non-specific") urethritis. There seems little doubt that in previous years reviews of gc. arthritis have included patients with Reiter's syndrome (Lees, 1932; Myers and Gwynn, 1935; Keefer and Spink, 1937).

To clarify this situation it seemed desirable to review a large series of patients from the same hospital population who had arthritis in association with venereal disease. The study was of necessity retrospective in view of the changed incidence of gc. arthritis since the advent of specific drugs. Before the introduction of antibiotics it was estimated that 1 to 5 per cent. of patients with gonococcal urethritis developed gc. arthritis, whereas the incidence is now $0 \cdot 1-0 \cdot 3$ per cent. (Balboni, 1960).

"Reiter's syndrome" is an unsatisfactory term, for, as Ford (1953) pointed out, Reiter's paper made a negligible if not somewhat misleading contribution to the subject, since he described a case following dysentery, and attributed the arthritis to a spirochaete, and confusion arises when ocular manifestations are absent, as indeed they usually are. However, the eponym has been retained on account of its wide usage, and the lack of a suitable alternative ("venereal arthritis" seems unsatisfactory since one can hardly say that gonococcal arthritis is not a venereal arthritis).

To ensure accuracy in delineating the clinical picture in the present series, strict criteria were laid down for the inclusion of cases in one of the three diagnostic categories: definite gc. arthritis, probable gc. arthritis, and Reiter's syndrome. The definite and probable diagnoses were distinguished not only to maintain certainty in the description of the clinical picture, but also to ascertain the likelihood of the diagnosis "probable gc. arthritis" being correct. The strictness of the criteria necessitated the exclusion of 62 of the original series of 214 patients. In ten of these the clinical picture accorded exactly with that of probable gc. arthritis, but the failure to find gonococci (which was possibly due merely to the well-known difficulty of growing the organism) necessitated their exclusion.

Comparison of Definite and Probable Gonococcal Arthritis.-This distinction was based on the presence or absence of gonococci in joint aspirate or tendon sheath effusion. In no aspect was there any significant difference between the two groups, and their similarity was in striking contrast to the clinical picture of Reiter's syndrome. It seems that a diagnosis of gc. arthritis may be considered likely in a patient who, within 3 weeks of having gonococcal urethritis or cervicitis, develops an acute arthritis which responds to sulphonamide or penicillin therapy, despite the absence of gonococci in joint fluid. Nevertheless, certainty is impossible in the absence of cultural evidence. A patient may have undoubted non-specific urethritis and then go on to develop an acute monarticular arthritis. Regardless of the type of treatment administered, the symptoms may subside rapidly within 3 or 4 days (Oates, 1962).

The following cases illustrate the likelihood of the 
diagnosis despite the absence of the prescribed criteria.

Cases 4 and 5.-A 19-year-old coloured woman was admitted the day before delivery of a full-term child. She complained of a stiff neck which had developed suddenly. On admission she had a temperature of $101^{\circ} \mathrm{F}$. Arthritis rapidly involved the metacarpophalangeal joints and the left wrist. The joints showed swelling, tenderness, and painful limitation of movement. A cervical smear revealed gonococci microscopically and on culture. Sulphathiazole was given and within a week all symptoms had subsided.

The day after admission this woman gave birth to a normal son. When 12 days old he developed gonococcal proctitis, and 2 days later his ankles became painful, red, and swollen, followed by involvement of the proximal interphalangeal joint of the left middle finger and both wrists. $X$-ray examination of the ankles showed only soft tissue swelling. Sulphathiazole was given and in 2 weeks all symptoms and signs had abated.

Both mother and son were followed for 12 years and showed no residual disability or recurrences.

The circumstantial evidence for a diagnosis of gc. arthritis in these two patients seems particularly strong. Simultaneous gc. arthritis in mother and neonate has been reported previously (Hench and others, 1938), but is rare (Olin, 1954).

Case 6, a coloured baby girl, was born of a mother with gonococcal cervicitis, and 3 days after birth, developed gonococcal conjunctivitis, which was treated with local irrigation. The next day the metacarpophalangeal joints of both hands became swollen, red, hot, and tender. The white blood count was 26,000 per c.mm. and $x$-ray examination of the hands showed no abnormality. Sulphathiazole was given and in 3 days all symptoms and signs had cleared.

Case 7, a coloured girl aged 3 years, developed gonococcal vaginitis. One week later the left knee became painful and swollen so that she could not stand. The right knee and right ankle were then involved, and she was admitted to hospital with a temperature of $103^{\circ} \mathrm{F}$. The haemoglobin level was 70 per cent., the white blood cell count 17,000 per c.mm., and gonococci were seen on smear of the vaginal discharge. She was treated with mercurochrome and over a period of 4 weeks symptoms and signs gradually abated. There was no residual disability and, during a period of 12 years' observation, no recurrence.

The circumstantial evidence for the diagnosis of gc. arthritis in these four illustrative cases seems very strong.

Clinical Picture of Gonococcal Arthritis.-The belief that the majority of so-called cases of gc. arthritis were in fact examples of Reiter's syndrome (Harkness, 1950; Ford, 1953; Kelly, 1958) has not been substantiated. Gc. arthritis occurred more commonly in women between 16 and 25 years of age, and usually followed 3 weeks after gonococcal urethritis, as others have found (Copeman, 1955; Balboni, 1960). In one patient, however, there was no preceding urethritis, and the only focus was a pustule on the finger:

Case 8, a coloured male child, was born of a mother who had been treated for syphilis during pregnancy. 3 weeks after birth it was noted that the baby was unable to extend the right hip, and 3 days later a pustule developed on the right index finger, the inflammation spreading to involve the palm. Examination of the hip showed a flexion deformity with pain on forcible extension. There was overlying swelling. The axillary and cervical lymph nodes were palpable, and the liver and spleen could be felt. Gonococci were isolated from the finger lesion, but the urine was sterile and contained no cells or albumen. $X$-ray examination of the hips and fingers showed no abnormality. The patient was treated with sulphathiazole and all disability cleared within 10 days, and during 9 years' observation there was no recurrence.

The onset was usually monarticular, involving the central joints, mostly in the upper limbs; it was almost invariably accompanied by constitutional disturbances, and a temperature above $101^{\circ} \mathrm{F}$. was found in more than half the patients on admission. A polyarthritis developed which most commonly affected the knee, shoulder, elbow, and wrist. Tenosynovitis was a prominent feature in some patients, and was occasionally the only manifestation, as illustrated by the following case:

Case 9, a 22-year-old white man, developed a mucopurulent urethral discharge 10 days after exposure, and was treated at home with sulphanilamide. One week after stopping the drug a tenosynovitis of the right extensor pollicis tendon developed, and he was admitted to hospital with a temperature of $104 \cdot 8^{\circ} \mathrm{F}$. He had a urethral discharge in which gonococci were found on smear and culture, tenosynovitis, and a gland in the right axilla "the size of an English walnut". His white blood count was 17,000 per c.mm. A course of sulphanilamide was given and in 4 days all symptoms and signs had cleared dramatically.

The acute attack usually subsided in 4 weeks. When residual disability was present this commonly affected the knee and occasionally the hip, ankle, or wrist.

Hench has described in detail an arthritis of rheumatoid type precipitated by gonococcal infection (Hench, 1946; Hench and others, 1948; Hench and Boland, 1946), but the eight patients with rheumatoid arthritis who were excluded from the final analysis in the present study did not fit his clinical description of atypical rheumatoid arthritis, and there was only one patient in whom it seemed that this sequence of events might have occurred. 
Case 10, a 47-year-old coloured man, was observed for 28 years as a patient. He began in 1932 with acute arthritis of the knees lasting 3 weeks, associated with a urethral discharge. 4 years later arthritis of the left knee recurred. $70 \mathrm{ml}$. fluid were aspirated from the knee and gonococci were isolated by smear and culture. This episode also subsided spontaneously in 3 weeks. A third attack occurred 10 years later, 2 days after an operation for strangulated hernia. The arthritis affected the knees and tarsus and subsided after treatment with sulphadiazine. At that time fluid was aspirated twice from the right knee and three times from the left, but no organisms were found. Six years later (1948) he was noted to have severe osteo-arthritis of the knees, both clinically and radiologically. Between 1951 and 1956 he had four attacks of acute arthritis affecting the right wrist, right shoulder, left knee, and both knees respectively. The last attack occurred a week after a bout of diarrhoea for which no cause was found. His white blood count at that time was 10,550 per c.mm., haemoglobin $12.5 \mathrm{~g}$. per cent., serum uric acid $3.4 \mathrm{mg}$. per cent., serum albumin $3.9 \mathrm{mg} . / 100 \mathrm{ml}$, and serum globulin $3.8 \mathrm{mg} . / 100 \mathrm{ml}$. On two occasions the Waaler-Rose differential agglutination test was positive at a titre of 32 . An $x$-ray examination of the hands revealed no abnormality.

This case shows many points of interest. First, proven gc. arthritis occurring before the advent of sulphonamides subsided spontaneously. Secondly, there were frequent recurrences of the condition over a period of 28 years, which is unlike the normal course of gc. arthritis in this and other series (Short, Bauer, and Reynolds, 1957). Thirdly, this patient would be deemed to have definite rheumatoid arthritis by the criteria of the American Rheumatism Association (Ropes, Bennett, Cobb, Jacox, and Jessar, 1959). It might be argued that, in fact, this patient had two diseases, gc. arthritis and Reiter's syndrome. Against this is the finding on two occasions of a positive differential agglutination test, which is almost invariably negative in cases of Reiter's syndrome (Wright, 1957; Jacobson, Kammerer, Wolf, Epstein, and Heller, 1956; McEwen, Ziff, Carmel, DiTata, and Tanner, 1958; Kellgren, Ball, and Bier, 1959; Wilson, Morison, and Wright, 1960). Hench's studies were made before the differential agglutination test was in general use, and it may well be that his cases of "rheumatoid arthritis provoked by gonorrhoea" were in fact examples of Reiter's syndrome occurring in subjects who also had gonococcal urethritis.

Difference between Gonococcal and Pyogenic Arthritis.-Although gc. arthritis is caused by a specific organism which produces a purulent discharge from tissues such as the mucous membrane of the urethra, cervix, vagina, and conjunctivae, the clinical presentation of the arthritis differs from that of other types of arthritis caused by bacteria. Some authors have emphasized the destructive character of gc. arthritis (Harrison, Beeson, Resnik, Thorn, and Wintrobe, 1950; Ford, 1958) and have referred to its devastating nature if left untreated (Hench, 1946), but in this series, even before sulphonamides and penicillin were available, the majority of patients recovered without residual disability, whereas the joints of most patients with pyogenic arthritis show some damage (Chartier, Martin, and Kelly, 1959). Only in 17 per cent. of the patients with definite gc. arthritis and in 23 per cent. of those with probable gc. arthritis was the disease confined to one joint, whereas a polyarthritis is rare in pyogenic arthritis. Of 77 cases of bacterial arthritis reported from the Mayo Clinic, only two had more than one joint involved (Chartier and others, 1959). The migratory nature of the arthritis observed in 29 per cent. of patients with gc. arthritis is unusual in pyogenic arthritis. In patients in whom gc. arthritis finally became localized in a single joint, those previously involved showed no residua. All these points raise the possibility of a "hypersensitivity factor" in the arthritis, similar to that thought to operate in rheumatic fever, which the arthritis often resembled at certain stages. The clinical picture was certainly not that of a single infected joint.

Reiter's Syndrome.-The 51 patients whowere considered to have Reiter's syndrome formed a valuable group for comparison with gc. arthritis, since they were all drawn from the same hospital population. Some authors insist on the complete triad of urethritis, conjunctivitis, and arthritis for the diagnosis of Reiter's syndrome (Weinberger and Bauer, 1955; Smyth and others, 1959), but since many years may intervene before conjunctivitis develops (Csonka, $1958 \mathrm{a}, \mathrm{b})$, or it may be so mild that it escapes the patient's notice (Paronen, 1948; Hollander, 1953), it seemed advisable to include patients with abacterial urethritis and arthritis in this category, as others have done (Ford, 1958; Reynolds and Csonka, 1958). In 23 patients there was concomitant gonococcal infection, but with specific treatment this cleared, without affecting the arthritis and leaving a non-specific urethritis.

Although described nearly 150 years ago (Brodie, 1818) and achieving its eponym from the description of Hans Reiter (1916), the syndrome has become more widely recognized since the studies of Harkness (1950), Csonka (1958a, b, 1960), Ford (1953, 1958), and others at the London Hospital (Murray, Oates, and Young, 1958; Oates and Young, 1959; Catterall and Perkins, 1961). The majority of the present 
patients had been labelled as cases of gc. arthritis, before the wider recognition of Reiter's syndrome, on the basis of concomitant arthritis and urethritis venereally acquired.

The disease resembled gc. arthritis in that the onset of arthritis was usually acute and accompanied by constitutional disturbances. It affected the central joints asymmetrically initially, and during its course commonly involved the knees and ankles. It differed from gc. arthritis in that white patients were more often affected than coloured ones and women rarely suffered. The predilection for men is so marked, in fact, that great caution must be exercised in diagnosing the condition in women (Refvem, 1957; Oates and Csonka, 1959). More patients were affected after the age of 25 years. Involvement was more often polyarticular than monarticular at the onset, but the arthritis began much less frequently in the shoulders and other joints of the upper limbs than did gc. arthritis; the elbow was never involved at all. The heel was sometimes the site of onset, which never occurred in cases of gc. arthritis, and the heels and lumbar spine were much more often involved during the course of the disease. Tenosynovitis, sometimes the only manifestation of involvement of the locomotor system, was not seen in Reiter's syndrome, although other authors have noted Achilles tendinitis in 12.9 per cent. and involvement of other tendons, notably the patella tendon, in 7 per cent. (Reynolds and Csonka, 1958). Recurrences were much more frequent with Reiter's syndrome, response to therapy was poor, and residual disability was commoner. Residual disability was limited to one joint and was confined to the knee, hip, or wrist in gc. arthritis, but the shoulder, ankle, heel, metatarsophalangeal joints, and/or lumbar spine might also be permanently damaged in Reiter's syndrome and more than one joint might be affected. The association of calcanean spurs and abacterial urethritis is being increasingly recognized (Ford, 1958; Engleman, 1960). The spinal involvement in Reiter's syndrome was indistinguishable clinically and radiographically from ankylosing spondylitis, and spondylitis seems to be the chief cause of residual disability in Reiter's syndrome (Lefkovits and Thomas, 1958; Mason, Murray, Oates, and Young, 1959). Sharp (1957), in a detailed study of 530 patients attending a special clinic for the investigation and treatment of spondylitis, found that one in five presented unusual features. Of these atypical spondylitics, who responded poorly to radiotherapy (Sharp and Easson, 1954), twenty had Reiter's syndrome. Forestier (1939), in reviewing 139 patients with ankylosing spondylitis, found a history of genito-urinary infection in 60 per cent. A correlation between chronic prostatitis and ankylosing spondylitis has been demonstrated (Romanus, 1953; Mason, Murray, Oates, and Young, 1958), but its significance is still obscure. It has been suggested that, since ankylosing spondylitis may accompany ulcerative colitis (Bywaters and Ansell, 1958; Wright and Watkinson, 1959), organisms may penetrate the mucosa in the pelvic region, causing sacro-iliitis and generalized arthritis (Romanus, 1953; Grainger, 1959). Some have included the arthritis of ulcerative colitis in the category of Reiter's syndrome (Ford, 1958). However, our studies show that colitic arthritis follows a different clinical course from that of Reiter's syndrome and seldom causes residual disability apart from spinal involvement (Wright and Watkinson, 1959).

Extra-articular manifestations were encountered in Reiter's syndrome more often than in gc. arthritis. An abacterial conjunctivitis is, of course, part of the classical triad. Ulcers of the buccal mucous membrane, a less usual manifestation, were noted in the present study. Circinate balanitis, a typical feature, according to Ford (1958), was found in seven patients. Keratodermia blennorrhagica, ascribed to gonorrhoea by Combes, Dietrich, and Cohen (1940) and Gateley (1945), was found only in patients with Reiter's syndrome. Rare manifestations, such as neurological lesions (Csonka, 1958a, b; Oates and Hancock, 1959) and cardiac involvement (Csonka and Oates, 1957; Csonka, Litchfield, Oates, and Willcox, 1961), were not observed among these patients.

Diagnostic Difficulties.-Gonococci could not be isolated in the vaginal discharge of more than half the women with definite gc. arthritis; the organism is not easily cultured even on special media, and it could be cultured in only 43 per cent. of 81 patients in whom gonococci were seen in smears of secretions from the urogenital tract.

Apart from the finding of gonococci in the joint fluid, laboratory tests were of little value. Abacterial urethritis in association with arthritis is, of course, suggestive of Reiter's syndrome, but concomitant gonococcal urethritis was present in 45 per cent. of the patients. The gonococcal complement-fixation test was of no value; it was negative in 13 per cent. of 38 patients with proven gonorrhoea, and the percentage of positive results was virtually the same in Reiter's syndrome and gc. arthritis.

A mild anaemia and a raised erythrocyte sedimentation rate were equally common in all cate- 
gories, although in Reiter's syndrome the raised E.S.R. persisted for longer periods. A white blood count of over 16,000 per c.mm. was more in keeping with gc. arthritis than with Reiter's syndrome.

Differentiation must therefore be made largely on clinical grounds and on response to therapy, but even this may be difficult, as illustrated by the following cases:

Case 11, a 49-year-old coloured man, had gonorrhoea in 1918, accompanied by pain in the ankles and heels which lasted 10 weeks. He then had no further trouble for 8 years, when his feet began to ache and a polyarthritis involved the temporo-mandibular joints, left knee, left hip, wrists, shoulders, and elbows. There was marked limitation of spinal movement and $x$-ray examination showed ankylosis of the sacro-iliac joints. There was no urethritis, but a chronic prostatitis was present and gonococci were seen in the smear of fluid obtained by prostatic massage. The clinical diagnosis was one of Reiter's syndrome, but joint fluid aspirated from the left knee on two occasions showed gonococci on smear and culture. One is tempted to suggest that in fact this patient had both Reiter's syndrome and gc. arthritis.

Case 12 illustrates the difficulty in diagnosis that may be caused by recurrent arthritis.

Case 12, a 28-year-old coloured woman, was being treated for syphilis in 1929 when she developed arthritis of the shoulders and right sternoclavicular joint, together with a scaly rash of the palms and soles. These features subsided and she had no further trouble until she was 35 years old, when pain and swelling of the right ankle developed. $X$-ray examination showed no abnormality, and the condition subsided spontaneously. One year later, after 2 months of lassitude, headaches, anorexia, and loss of weight, the left knee became swollen and painful. An $x$-ray examination showed only soft tissue swelling. $75 \mathrm{ml}$. fluid were aspirated from the joint and culture grew gonococci. The patient became symptom free after one week's treatment with sulphanilamide. The course of her illness suggested Reiter's syndrome, but the presence of gonococci in the joint fluid substantiated the aetiology of the last attack.

Case 13 is a good example of a patient who appeared to have gc. arthritis, but was in fact a case of Reiter's syndrome:

Case 13, a 16-year-old white youth, developed a purulent urethral discharge 6 days after sexual intercourse. 2 days later an acute arthritis affected the right knee, ankles, and right elbow. On admission to hospital he appeared very ill and drowsy with a temperature of $103^{\circ} \mathrm{F}$. Gonococci were easily recovered from the urethral discharge, a diagnosis of gc. arthritis was made, and treatment with sulphathiazole was instituted. The urethral discharge quickly diminished, but a slight mucoid discharge remained. He remained pyrexial and it was 4 months before the swinging temperature gradually reverted to normal. The joints remained inflamed and both knees were involved. On three occasions 100,70 , and $125 \mathrm{ml}$. fluid respectively were aspirated from the knees. No organisms were seen or grown from the aspirate in which the sulphonamide level was $5.9 \mathrm{mg} . / 100 \mathrm{ml}$. on the second tap (blood level $7.8 \mathrm{mg} . / 100 \mathrm{ml}$.). Circinate balanitis and ulceration of the buccal mucosa developed. The arthritis gradually subsided and he was discharged with restricted movement of the knees and ankles and ankylosed wrists. At the age of 19 years, 3 years later, he had an acute exacerbation in the right knee, from which a total of $350 \mathrm{ml}$. sterile fluid were aspirated on four occasions. He had a temperature of $102^{\circ} \mathrm{F}$. which settled in one month Seven years later he developed acute pain in the left shoulder. $X$-ray examination showed a roughened head of the left humerus in the region of the bicipital tendon In the following year he was noted to have pain and stiffness of the back and neck.

Harrison and others (1950) stated that the diagnosis of gonococcal arthritis is simple, particularly in patients with acute polyarthritis following a gonococcal urethral discharge, but in practice it may sometimes be difficult.

Effect of Therapy.-The introduction of sulphonamides and penicillin has altered the course and prognosis of gonorrhoea, as is well shown by analysis of the three eras under survey in the present study. It is interesting that the incidence of gc. arthritis was similar in all three periods; the differences lay in residual disability and duration of attack. Neither the course nor the outcome of Reiter's syndrome was helped by sulphonamide or penicillin therapy. Indeed, the number of patients with Reiter's syndrome lasting over 2 months was relatively greater in the penicillin era.

\section{Summary}

The notes of 214 patients labelled as cases of gonococcal arthritis were re-examined. 62 were excluded and the rest classified as cases of definite gonococcal arthritis, probable gonococcal arthritis, and Reiter's syndrome.

The clinical pictures of definite and probable gonococcal arthritis corresponded closely. There was a greater incidence among women, more coloured people were affected than white, and the arthritis usually began between 16 and 25 years of age.

Other points distinguishing gonococcal arthritis from Reiter's syndrome were that the arthritis often began acutely in only one joint. In Reiter's syndrome at the onset pyrexia was less common, upper limb joints were less frequently involved (the shoulder rarely, and elbow never), and the heel was sometimes the site of onset.

During the course of Reiter's syndrome, the lumbar spine and the heel were more often affected and the arthritis was more often symmetrical. On the other hand tenosynovitis was not observed at all, 
and migratory arthritis was rare. In gonococcal arthritis the acute attack quickly subsided, recurrences were rare, and residual damage was less usual and was confined to one joint in all but one case. Limitation of ankle movement was more common with Reiter's syndrome, which was also characterized by residual shoulder and spine involvement, and painful heels and metatarsophalangeal joints. Keratodermia blenorrhagica and circinate balanitis were found only in patients with Reiter's syndrome. Ocular complications occurred in 22 patients with Reiter's syndrome compared with only 5 of the rest.

The gonococcal complement-fixation test was of no help in distinguishing the types of arthritis. A mild anaemia and raised erythrocyte sedimentation rate was common in all groups, but leucocytosis was commoner in cases of gonococcal arthritis. Radiological changes were found more frequently in patients with Reiter's syndrome.

I am grateful to Dr. Richard J. Johns and Dr. R. D. Catterall for helpful criticism, and to Dr. Lawrence E. Shulman for discussion in the preparation of the study.

\section{REFERENCES}

Balboni, V. G. (1960). In "Arthritis", ed. J. L. Hollander, 6th ed., pp. 927-41. Kimpton, London.

Brodie, B. C. (1818). "Pathological and Surgical Observations on Diseases of the Joints," p. 54. Longman, London.

Bywaters, E. G. L., and Ansell, B. M. (1958). Ann. rheum. Dis., 17, 169.

Catterall, R. D., and Perkins, E. S. (1961). Brit. J. Ophthal., 45, 109.

Chartier, Y., Martin, W. J., and Kelly, P. J. (1959). Ann. intern. Med., 50, 1462.

Combes, F. C., Dietrich, C., and Cohen, J. (1940). J. Amer. med. Ass., 140, 2078.

Copeman, W. S. C. (1955). "Textbook of Rheumatic Diseases", p. 535. Livingstone, Edinburgh.

Csonka, G. W. (1958a). Brit. med. J., 1, 1088.

- (1958b). Ann. rheum. Dis., 17, 334.

- (1960). Arthr. and Rheum., 3, 164.

- -, Litchfield, J. W., Oates, J. K., and Willcox, R. R. (1961). Brit. med. J., 1, 243.

—_ and Oates, J. K. (1957). Ibid., 1, 866.

Engleman, E. P. (1960). In "Arthritis", ed. J. L. Hollander, 6th ed., pp. 942-58. Kimpton, London.

Ford, D. K. (1953). Ann. rheum. Dis., 12, 177.

- (1958). Bull. rheum. Dis., 8, 159.

Forestier, J. (1939). Radiology, 33, 389.

Gateley, J. R. (1945). U.S. Nav. Med. Bull., 45, 1159.

Grainger, R. G. (1959). J. Fac. Radiol., 10, 138.

Harkness, A. H. (1950). "Non-gonococcal Urethritis", pp. 99-145. Livingstone, Edinburgh.
Harrison, T. R., Beeson, P. B., Resnik, W. H., Thorn, G. W., and Wintrobe, M. M. (1950). "Principles of Internal Medicine", p. 834. Blakiston, Philadelphia.

Hench, P. S. (1946). J. Amer. med. Ass., 132, 974.

and Boland, E. W. (1946). Ann. intern. Med., 24, 808.

and 6 others (1938). Ibid., 11, 1089.

and 10 others (1948). Ibid., 28, 77.

Hollander, J. L. (1953). "Comroe's Arthritis", 5th ed. Kimpton, London.

Jacobson, A. S., Kammerer, W. H., Wolf, J. Epstein, W. V., and Heller, G. (1956). Amer. J. Med., 20, 490.

Keefer, C. S., and Spink, W. W. (1937). J. Amer. med. Ass., 109, 1448.

Kellgren, J. H., Ball, J., and Bier, F. (1959). Brit. med. J., 1, 523.

Kelly, M. (1958). Ibid., 2, 449.

Lees, D. (1932). Brit. J. vener. Dis., 8, 79, 192.

Lefkovits, A. M., and Thomas, J. R. (1958). Ann. intern. Med., 49, 89.

Mason, R. M., Murray, R. S., Oates, J. K., and Young, A. C. (1958). Brit. med. J., 1, 748.

,,,$----(1959)$. J. Bone Jt Surg., 41B, 137.

McEwen, C., Ziff, M., Carmel, P., DiTata, D., and Tanner, M. (1958). Arthr. and Rheum., 1, 481.

Murray, R. S., Oates, J. K., and Young, A. C. (1958). J. Fac. Radiol. (Lond.), 9, 37.

Myers, W. K., and Gwynn, H. B. (1935). Med. Ann. Distr. Columb., 4, 194.

Oates, J. K. (1962). Personal communication. and Csonka, G. W. (1959). Ann. rheum. Dis., 18, 37. and Hancock, J. A. H. (1959). Amer. J. med. Sci., 238, 79. and Young, A. C. (1959). Brit. med. J., 1, 1013.

Olin, T. E. (1954). Ann. Chir. Gynaec. Fenn., 43, Suppl. 5, p. 279.

Paronen, I. (1948). Acta med. scand., Suppl. 212.

Refvem, O. (1957). Acta rheum. scana., 3, 282.

Reiter, H. (1916). Dtsch. med. Wschr., 42, 1535.

Reynolds, D. F., and Csonka, G. W. (1958). J. Fac. Radiol. (Lond.), 9, 44.

Romanus, R. (1953). Acta med. scand., 145, Suppl. 280, p. 177.

Ropes, M. W., Bennett, G. A., Cobb, S., Jacox, R., and Jessar, R. A. (1959). Arthr. and Rheum., 2, 16.

Sharp, J. (1957). Brit. med. J., 1, 975.

and Easson, E. C. (1954). Ibid., 1, 619.

Short, L. C., Bauer, W., and Reynolds, W. E. (1957). "Rheumatoid Arthritis", pp. 59-67. Harvard University Press, Cambridge, Mass.

Smyth, C. J., and others (1959). 12th Rheumatism Review, Ann. intern. Med., 50, 434.

Weinberger, H. J., and Bauer, W. (1955). Med. Clin. N. Amer., 39, 587.

Wilson, J. V., Morison, R. A. H., and Wright, V. (1960). J. clin. Path., 13, 453.

Wright, V. (1957). Univ. Leeds med. J., 6, 98. and Watkinson, G. (1959). Medicine (Baltimore), 38, 243. 
Arthrite associée á la maladie vénérienne

\section{RÉSUMÉ}

On a passé en revue 214 dossiers marqués comme cas d'arthrite gonococcique. On en a exclu 62 et on a classé les autres comme cas d'arthrite gonococcique confirmée, arthrite gonococcique probable et de syndrome de Reiter.

Les tableaux cliniques de l'arthrite gonococcique confirmée et probable se ressemblaient de près. On la trouvait plus souvent chez des femmes, plus de personnes de couleur que de race blanche étaient affectées, et elle commençait habituellement entre l'âge de 16 et de 25 ans.

Parmi les traits qui distinguaient l'arthrite gonococcique du syndrome de Reiter se trouvait le fait que l'arthrite commençait souvent d'une manière aiguë et dans une seule articulation. Dans le syndrome de Reiter la fièvre au début était peu commune, les articulations des membres supérieurs étaient moins souvent impliquées (l'épaule rarement, le coude jamais) et le talon était quelquefois premier à être atteint.

Pendant l'évolution du syndrome de Reiter, l'épine lombaire et le talon se trouvaient affectés plus souvent, tandis que dans l'arthrite l'atteinte était plus souvent symétrique. D'autre part, la ténosynovite de la main n'a pas été observée et l'arthrite migrante était rare. Dans l'arthrite gonococcique les attaques aigues passaient rapidement, les rechutes étaient rares et les séquelles peu communes et limitées à une seule articulation dans tous les cas sauf un. La limitation du mouvement de la cheville étaient plus commune dans lesyndrome de Reiter, caractérisé aussi par l'atteinte résiduelle de l'épaule et de la colonne vertébrale et par la douleur aux talons et articulations métatarsophalangiennes. La kératodermie blennorragique et la balanite circinée ne se rencontraient que chez des malades atteints de syndrome de Reiter. Des complications oculaires furent notées chez 22 malades atteints de syndrome de Reiter mais seulement chez 5 parmi les autres.

La réaction gonococcique de fixation du complément était peu utile pour distinguer entre les types d'arthrite. Une anémie benigne et la vitesse de sédimentation érythrocytaire augmentée étaient communes dans tous les groupes, mais la leucocytose s'observait plus souvent dans des cas d'arthrite gonococcique. Des altérations radiologiques ont été trouvées plus souvent chez des malades atteints de syndrome de Reiter.

\section{Artritis asociada con enfermedad venerea}

\section{Sumario}

Las notas clínicas de 214 enfermos marcados como casos de artritis gonocócica fueron revisadas. De estos, 62 fueron excluidos y los restantes se clasificaron como casos de artritis gonocócica probada, artritis gonocócica probable y síndrome de Reiter.

Los cuadros clínicos de artritis gonocócica probada y probable se correspondieron estrechamente. La incidencia fué mayor entre las mujeres; menos sujetos co de raza blanca que de raza de color eran afectos y la artritis generalmente empezaba entre los 16 y 25 años de edad.

Otros puntos que distinguieron la artritis gonocócica del sindrome de Reiter fueron que la artritis a menudo empezaba de un modo agudo en una sola articulación; en el síndrome de Reiter fiebre en el comienzo fué más rara, las articulaciones del miembro superior eran menos $\mathrm{N}$ frecuentemente afectadas (el hombro raramente, el codo i nunca) y el talon era a veces el lugar de comienzo.

Durante el curso del síndrome de Reiter la espina lumbar y el talon se vieron afectados más a menudo, mientras que en la artritis las lesiones eran más frecuente- mente simétricas. Por otra parte, tenosinovitis de la $\zeta$ mano no se observó nunca y la artritis migratoria fué ミ rara. En la artritis gonocócica el ataque agudo se $\rho$ resolvía rapidemente, las recaidas fueron raras y las secuelas fueron menos frecuentes y limitadas a una articulación en todos los casos menos uno. Limitación de los movimientos del tobillo fué más común en el síndrome de Reiter, que además se caracterizaba por alteraciones residuales en el hombro y en la columna vertebral y por dolor en los talones y en las articulaciones metatarsofalangianas. La queratodermia blenorrágica y la balanitis circinata se encontraron solamente en enfermos del síndrome de Reiter. Complicaciones oculares sobrevinieron en 22 enfermos del síndrome de Reiter pero sólo en cinco de los demás.

La reacción gonocócica de fijación del complemento no sirvió de mucho para distinguir entre los tipos de artritis. Una ligera anemia y elevada velocidad de sedimentación eritrocitaria se encontraron en todos los grupos, pero leucocitosis fué más común en los casos de artritis gonocócica. Alteraciones radiológicas se encontraron más frecuentemente en enfermos del 3 síndrome de Reiter. 